\title{
On the Treating of Lead Polluted Water: Flotation of Lead Colloidal Carbonate
}

\author{
Francisco J. Tavera, ${ }^{1}$ Martín Reyes P., ${ }^{2 *}$ Ramiro Escudero G. ${ }^{1}$ and Francisco Patiño C. ${ }^{2}$ \\ ${ }^{1}$ Instituto de Investigaciones Metalúrgicas, Universidad Michoacana de San Nicolás de Hidalgo. Santiago Tapia 403, 58000, \\ Morelia Michoacán, México. E-mail tavera1950@gmail.com, ramiro1963@gmail.com \\ ${ }^{2}$ Universidad Autónoma del Estado de Hidalgo, Carretera Pachuca Tulancingo Km 4.5 42184. Pachuca, Hidalgo, México E-mail \\ mreyes@uaeh.edu.mx
}

Received April 20, 2010; accepted August 24, 2010

\begin{abstract}
The colloid flotation of lead carbonate in aqueous media is studied at $\mathrm{pH}$ 7. The flotation system consisted of five spargered flotation cells in a serial array. The flotation cells were operated under controlled conditions of superficial gas and liquid velocity, frother, and collector concentration. The measured variables were gas holdup, bubble size, superficial bubble surface flux, and lead recovery in the concentrate. The experimental data show that it is possible to separate up to $93 \%(\mathrm{w} / \mathrm{w})$ of lead from the aqueous media when the superficial gas velocity is $0.8 \mathrm{~cm} / \mathrm{s}$ and the superficial liquid velocity is 0.19 $\mathrm{cm} / \mathrm{s}$.
\end{abstract}

Keywords: colloid flotation, lead carbonate, flotation cell, frother, collector.

\section{Introduction}

The presence of heavy metals in waters at different locations in Mexico is often the result of poor control in the disposal of industrial waste materials [1]. This leads to serious environmental damage and the occurrence of human health problems; this issue requires proposals for engineering applications to remove those heavy metals from water.

Ion flotation is a technique for collecting a material being in solution, and may be as colloidal, in an aqueous phase. By modifying the chemical conditions and by adding a suitable collector appropriately charged. The dissolved or colloidal substance is converted into a product that has hydrophobic sites and it can be attached to a bubble. The swarm of bubbles produce a froth which concentrates the original substance that can be selectively collected [2].

Some studies about the complex formation between $\mathrm{Pb}^{2+}$ ions and diphenylcarbazone (HDPC) followed by flotation with oleic acid (HOL) surfactant [3] shown that the organic compound with large carbons chain is worth for recovery of precipitated metals. In other work lead was precipitated from aqueous nitrate and chloride solutions with sodium di-(n-octyl) phosphinate $(\mathrm{NaL})$ in the form of $\mathrm{PbL}_{2(\mathrm{~s})}$ achieving that the residual lead in solution were reduced by increasing the length of the alkyl group of the phosphinate to dodecyl [4]. Those investigations propose some organic compound for precipitation of metal, but they do not propose a method to separate this compound from solutions, this paper proposes a technique to recovery colloidal lead carbonate by colloidal flotation.

Most of the work on ion and colloid flotation has been done using flotation columns, perhaps influenced by the great
Resumen. Se estudio la flotación coloidal de carbonato de plomo a $\mathrm{pH}$ de 7.0, en un sistema en serie de cinco celdas de flotación, bajo condiciones controladas de velocidad superficial de gas y líquido, concentración de espumante y colector. Las variables medidas fueron: gas retenido, tamaño de burbuja, flujo de área superficial de burbujas y recuperación de plomo reportado en el concentrado. Los datos experimentales muestran que es posible separar el $93 \%(\mathrm{w} / \mathrm{w})$ de plomo como carbonato de plomo del medio acuoso, con una velocidad superficial de gas de $0.8 \mathrm{~cm} / \mathrm{s}$, y una velocidad superficial de líquido de $0.19 \mathrm{~cm} / \mathrm{s}$.

Palabras clave: flotación coloidal, carbonato de plomo, celda de flotación, espumante, colector.

performance of columns in mineral applications. Nevertheless, it has to be clear that flotation of particles requires bubbles with certain size that the density of the bubble particle aggregate be lower than the density of the pulp, the mixing of the system has to be controlled to avoid the particle detachment from the bubble surface [5]. In the case of ion flotation, the material to be separated from the liquid has a similar density than the liquid and the flow of phases around the moving bubbles is such that the material can be easily dragged. Therefore, it can be expected that contact between bubbles and material to be separated by flotation is enhanced if bubble size decreases. Furthermore, the production of small bubbles provides of large surface area for a given gas flow rate, which in turn will improve the separation process [5]. However, the rising bubbles in a column produce an axial mixing which leads to the presence of turbulence that reduces the probability of collision among phases during flotation. In this work, the use of flotation cells with porous spargers to produce a dispersed gas phase is analysed in terms of separating colloidal lead carbonate from tap water.

\section{Results and discussion}

\section{Effect of gas holdup on lead recovery}

The gas holdup was estimated by measuring the electrical conductivity of the continuous and disperses phases and applying Maxwell's model $[6,7]$. These measurements were validated against independent pressure measurements. Maxwell model relates the volumetric fraction of a non conducting phase in this case gas bubbles dispersed in a conducting continuum 
(liquid). The appropriate form of the model is $\varepsilon_{\mathrm{g}}=\left(\left\{1-\left[k_{\mathrm{d}} /\right.\right.\right.$ $\left.\left.\left.k_{1}\right]\right\} /\left\{1+0.5\left[k_{\mathrm{d}} / k_{1}\right]\right\}\right)$, where $\varepsilon_{\mathrm{g},} k_{\mathrm{d}}$ and $k_{1}$ are the gas holdup, the conductivity of the bulk and the conductivity of the liquid respectively [7].

The experimental data are presented in Figure 1, where the recovery of lead reported in the concentrate is plotted as a function of the average gas holdup in the collection zone of the flotation cell. It can be seen that the recovery of lead from the aqueous media increases with the gas holdup, due to an increase of the gas liquid interface available for the collection process. From Figure 1, there is a steady increase in the recovery of lead from the aqueous media as the gas holdup increases from $6.5 \%$ to $7.9 \%(\mathrm{v} / \mathrm{v})$, but above a gas holdup to $7.9 \%$, the lead recovery decreases due to an increase in the turbulence and mixing in the collection zone of the flotation cell.

\section{Effect bubble size on lead recovery}

Bubble size was estimated by applying the drift flux analysis to the experimental system [8]. Predictions of bubble size by drift flux analysis in two phase systems have proven to be very accurate as compared with direct measurements by image analysis [9]. The experimental data of lead recovery and bubble size estimates are presented in Figure 2. The increase in bubble size from $0.09 \mathrm{~cm}$ to $0.117 \mathrm{~cm}$ produces a clear effect in the collection process, decreasing the recovery of lead in the concentrate. From figure 2 the optimum bubble size for the highest lead recovery is $0.098 \mathrm{~cm}$. larger gas flow rates increase the amount of bubbles resulting in significant bubble coalescence because of the collision among them. On the other hand, the residence time of smaller bubbles increases with the mixing and this fact reduces the lead recovery; therefore, there is a clear effect of the hydrodynamics of the system on the collision process of the hydrophobic lead carbonate surfaces with bubbles. Rising velocity of bubbles increases with their size and it could cause that the colloidal lead carbonate be swept away from the bubble and the efficiency of the collection phenomenon decreases.

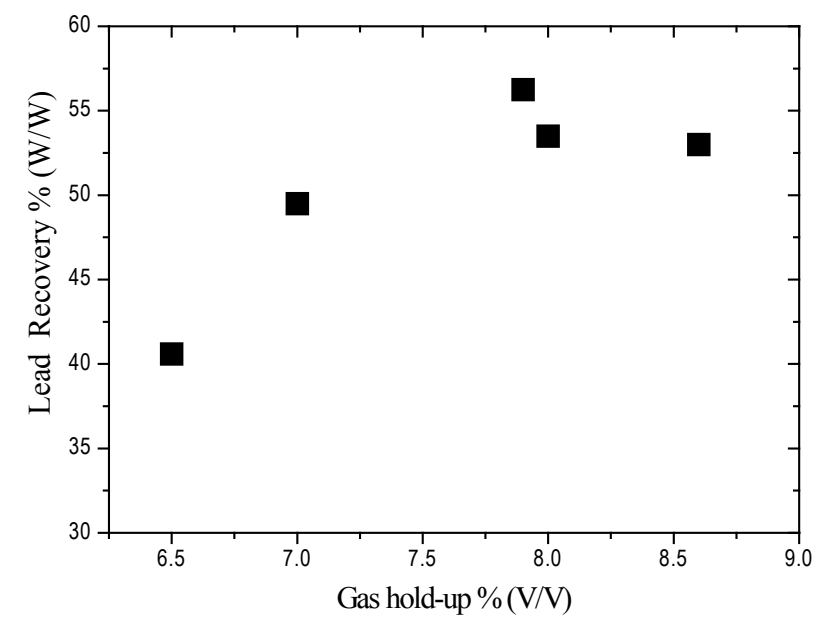

Fig. 1. Recovery of Lead Carbonate (\% w/w) from aqueous media in a spargered flotation cell operated under continuous regime.

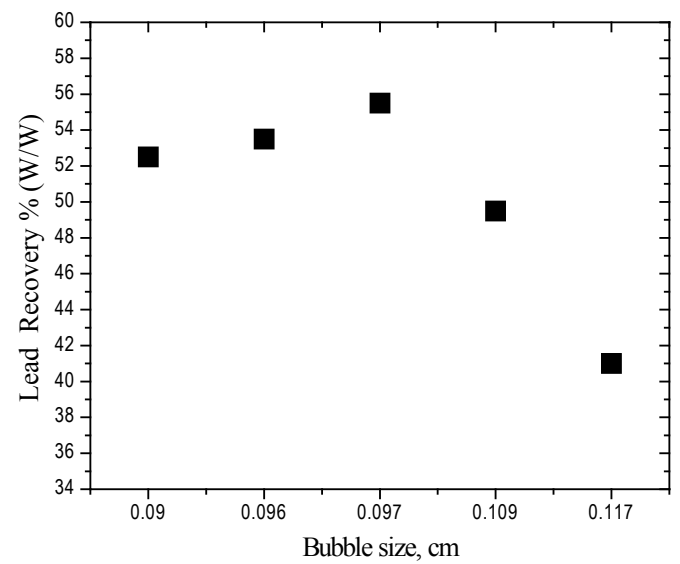

Fig. 2. Bubble size $(\mathrm{cm})$ effect on lead recovery as reported to the concentrate of lead carbonate precipitates.

\section{Relationship between the bubble surface area flux and the lead carbonate flotation}

The bubble surface area flux, $\mathrm{S}_{\mathrm{b}}$, has been presented as an operating variable which is related to the chemical, the hydrodynamics and the geometry characteristics of the flotation device, and it has been presented to be well tied to the kinetics of the flotation process [10]. Therefore, this variable could be worthy used as a control parameter because it holds all the properties of the flotation system. $\mathrm{S}_{\mathrm{b}}$ is defined as the amount of surface area of bubbles that crosses a unit cross section area of the cell per unit period of time; therefore, $S_{b}$ has units of time ${ }^{-1} . S_{b}$ can be readily estimated if flotation parameters such as bubble size $\mathrm{D}_{\mathrm{b}}$, and superficial gas velocity $\mathrm{J}_{\mathrm{g}}$ are known $\left(\mathrm{S}_{\mathrm{b}}=6 \mathrm{~J}_{\mathrm{g}} / \mathrm{D}_{\mathrm{b}}, \mathrm{s}^{-1}\right) ;[11]$.

Figure 3 presents the experimental data in terms of lead recovery as a function of the estimated bubble surface area flux. It can be seen that lead recovery increases with the bubbles surface area available to carry out the collection process; however, there is a maximum value of recovery for a maximum value of $S_{b}$ due to the coalescence of bubbles. Above this maximum of $S_{b}$, the lead recovery decreases due to the

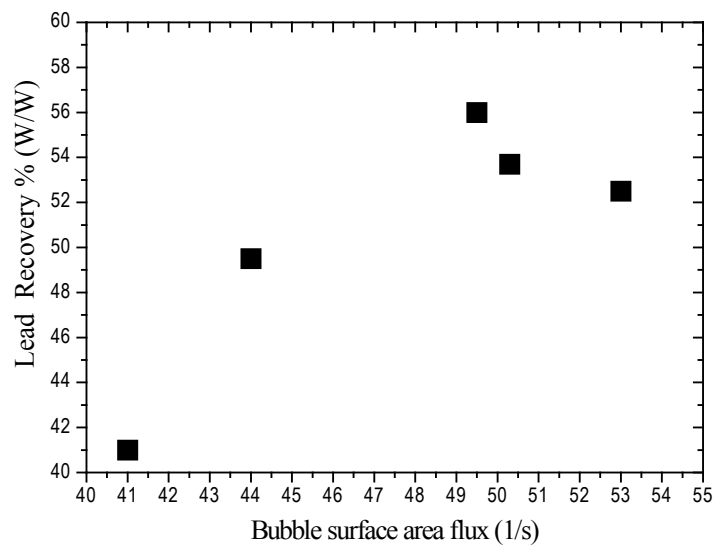

Fig. 3. Effect of the bubble surface area flux on the lead recovery reported to the concentrate. 
increase in the degree of mixing and circulation in the flotation system. This behavior is caused by large bubbles associated to high Jg values. This information indicates that the colloid flotation is very sensitive to the bubble size and, therefore, to the superficial phase velocity (gas, and liquid).

Under the present operating conditions, the flotation rate constant was estimated using the perfect mixing model given by $(\kappa=\mathrm{R} /\{\tau(1-\mathrm{R})\})$; [12]. Where $\tau$ is the apparent residence time in the collection zone and $\mathrm{R}$ is the fractional recovery of lead reported to the concentrate. The estimated flotation rate constant and the gas holdup are plotted in Figure 4. It can be observed that the flotation rate constant follows a linear relationship with the gas holdup for values up to $7.9 \% \mathrm{v} / \mathrm{v}$, above this value; the linear relationship between them disappears. The behaviour of the flotation rate constant as a function of the gas holdup (Figure 4) is consistent with the relationship among the lead recovery and the gas holdup. This information suggests that kinetics is strongly dependent of the hydrodynamics characteristics of this flotation system being the surface physicochemical properties overwhelmed by the former (hydrodynamics characteristics).

Figure 5 presents the flotation rate constant as a function of the bubble diameter. The information shows that in the

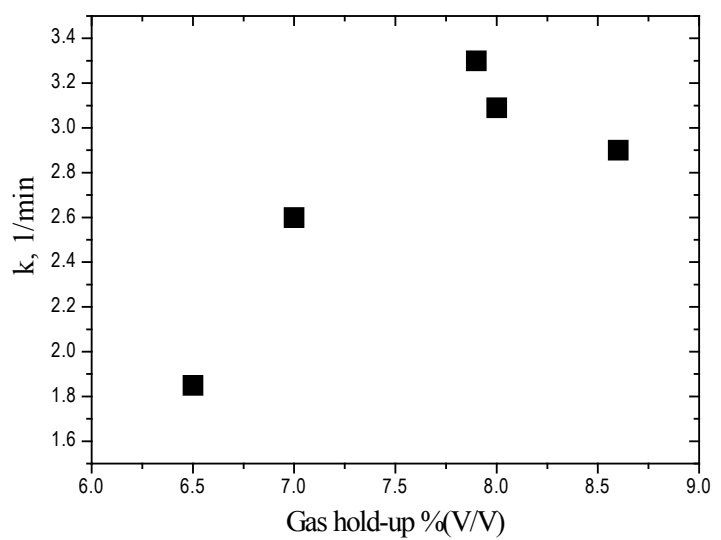

Fig. 4. Experimental data showing the Gas holdup effect on the flotation rate constant of the lead carbonate.

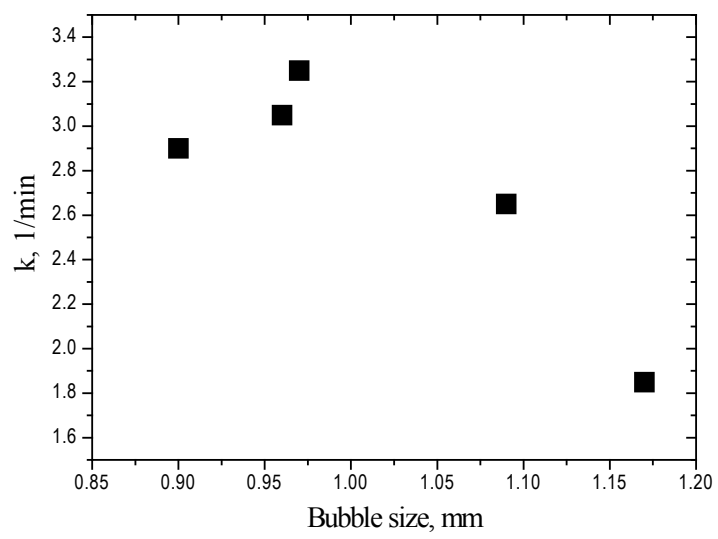

Fig. 5. Flotation of lead carbonate precipitates. Effect of the estimated bubble diameter on the flotation rate constant. range of bubble size between $0.097 \mathrm{~cm}$ and $0.1 \mathrm{~cm}$ there is a correlation between the kinetics and bubble size; in this range of bubble size, as expected, the kinetics of the flotation process are favoured by the decrease in bubble size. The bubble surface area flux decreases with bubbles size larger. This behaviour suggests that smaller bubbles increase the mixing and circulation, as a result of the larger gas holdup, and bubbles coalescence will be promoted producing a slight decrease in the $S_{b}$ value. This picture is reflected in the relationship between the kinetics of the flotation process and $\mathrm{S}_{\mathrm{b}}$.

\section{Overall lead recovery through the series of spargered flotation cells}

As mentioned above, the flotation system consisted of a series of five spargered flotation cells, where the tailings from one flotation cell is the feed to the next one and so on. In the operation of the flotation system, the superficial gas velocity was kept at $0.8 \mathrm{~cm} / \mathrm{s}$; the superficial liquid velocity at $0.19 \mathrm{~cm} / \mathrm{s}$; the aqueous phase contained $30 \mathrm{mgL}^{-1}$ of frother (Dowfroth 250). The former values were selected from groups of flotation tests as the best operating conditions to produce the highest recovery values of lead reported in the concentrate.

Figure 6 represents the values of the cumulative recovery of lead as a function of the number of flotation cells, for the five flotation cells. It can be seen that the cumulative recovery of lead through the "bank" of flotation cells is of around $93 \%$ $\mathrm{w} / \mathrm{w}$. The time for processing the water through the bank of flotation cells is $13 \mathrm{~min}$. This processing time seems to be very short, as compared to those periods of time in laboratory flotation columns (thirty to hundreds of minutes) [5]. It seems that the spargered flotation cell, produces bubbles of suitable sizes for the flotation of colloids, and reduces the axial and radial mixing that in a natural way is present in flotation columns [13]. Similar results were obtained on the sorption of $\mathrm{Pb}^{2+}$ ions from aqueous solutions onto limestone fines (LS),, where nearly $99 \%$ of $\mathrm{Pb}^{2+}$ ions were removed from aqueous solutions at $\mathrm{pH} 7$ after shaking for $5 \mathrm{~min}$ and at room temperature $(\sim 25$ $\left.{ }^{\circ} \mathrm{C}\right)[14]$.

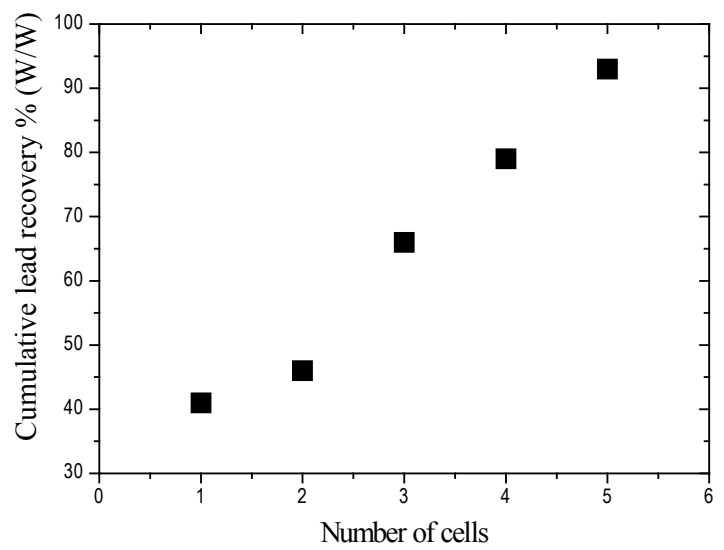

Fig. 6. Cumulative recovery of lead carbonate colloid as a function of the flotation cells number. 


\section{Conclusions}

It was found that lead carbonate exhibits negative $\zeta$ potential values in aqueous media when $\mathrm{pH}$ values are higher than 3.0 isoelectric point; therefore, in order to transform to hydrophobic the lead carbonate surface, a cationic collector should be added under $\mathrm{pH}$ values between 7 and 7.4. Dodecylamine is used as cationic collector in this work.

From experimental measurements spargered flotation cells are suitable to process water contaminated with colloid lead. Lead carbonate recoveries higher than $90 \%$ where achieve through froth flotation in a set of five spargered flotation cells. It can be expected that the separation of lead from the aqueous media should increase above $93 \%$ by increasing the number of flotation cells in the array. The required time to separate the lead carbonate is estimated in $13 \mathrm{~min}$.

This flotation process has shown to be strongly dependent on the hydrodynamics of the system, becoming the physicochemical surface properties overwhelmed by the former. Performance it was observed that the separation of lead from the aqueous phase is enhanced to some degree by increasing the gas holdup, the bubble surface area flux and decreasing bubble size. This flotation process appears to have a potential possibility for its application in treating polluted water for the removal of heavy metals as it shows lower mixing effects and shorter residence time compared to other flotation processes.

\section{Experimental, materials and methods}

\section{Apparatus}

The flotation experiments were carried out using a series of up to 5 flotation cells. Figure 7 represents schematically the experimental apparatus. The flotation cells were made of acrylic (19 cm wide, $19 \mathrm{~cm}$ long and $33 \mathrm{~cm}$ high); each cell was provided with a feed point located in one wall and the flotation tailings point located in the opposite wall. At the top of each cell, a launder to collect the flotation froth was installed. The cells were operated under continuous regime; the flotation tailings from the first flotation cell were taken as the feed for the second flotation cell, and so on. The feed and tailings flow rates in each cell were controlled by using calibrated with respect to volumetric flow rates peristaltic pumps. These pumps were used to estimate and define the liquid flow rate in the collection zone of the flotation cell during the experiment. The flow rates were expressed as superficial liquid velocities $\mathrm{Jl}=\mathrm{Ql} / \mathrm{Ac}$; $\mathrm{Jl}$ is the superficial liquid velocity, $\mathrm{cm} / \mathrm{s} ; \mathrm{Ql}$ is the volumetric flow rate, $\mathrm{cm}^{3} / \mathrm{s}$; and Ac, is the cross section area of the flotation cell, $\mathrm{cm}^{2}$.

Gas was fed in each flotation cell via cylindrical porous spargers located horizontally at the bottom of each cell. The gas flow rate was measured and controlled in each flotation cell by means of gas mass flow controllers. Again, the gas flow rate was expressed as superficial gas velocity. Gas holdup was measured in two ways: an average gas holdup measurement was done by knowing the value of hydrostatic pressure at two points located at different heights on a wall of the flotation cell; the location of the points for the pressure measurement was such that they were below the froth zone of the flotation cell $[15,16]$. Also, gas holdup was measured locally in different positions in the collection zone of the flotation cell using conductivity proves applying the phase separation method [16].

\section{Materials and their characterization}

The experimental aqueous media was prepared by dissolving lead nitrate in tap water in proportions to give a lead concentration $20 \mathrm{mgL}^{-1}$, once the lead nitrate was dissolved in the tap water, the aqueous media became cloudy. A sample of the cloudy water was taken to a centrifuge to separate the solids. The sediments from the centrifuge were analysed by $\mathrm{X}$ ray diffraction, and the results from this analysis showed that the sediments were lead carbonate. The separated lead carbonate was taken to a zeta $(\zeta)$ potential meter to determine its electrokinetics behaviour as $\mathrm{pH}$ was varied from 1.4 to 12 . Figure 8 represents the results of the $\zeta$ potential measurements. The lead carbonate $\zeta$ potential measurements show that the isoelectric point (IEP) occurs at $\mathrm{pH}=3.05$.

The $\mathrm{pH}$ of the liquid media was fixed at 7 and 7.4. Under such $\mathrm{pH}$ conditions, the $\zeta$ potential lead carbonate shows a negative charge, as shown in Figure 8 . Therefore, the flotation reagent should be a cationic collector (dodecylamine $\mathrm{C}_{12} \mathrm{H}_{27} \mathrm{~N}$ ), to create hydrophobic sites. Dodecylamine was added in molar proportion of 1:1 with respect to the lead

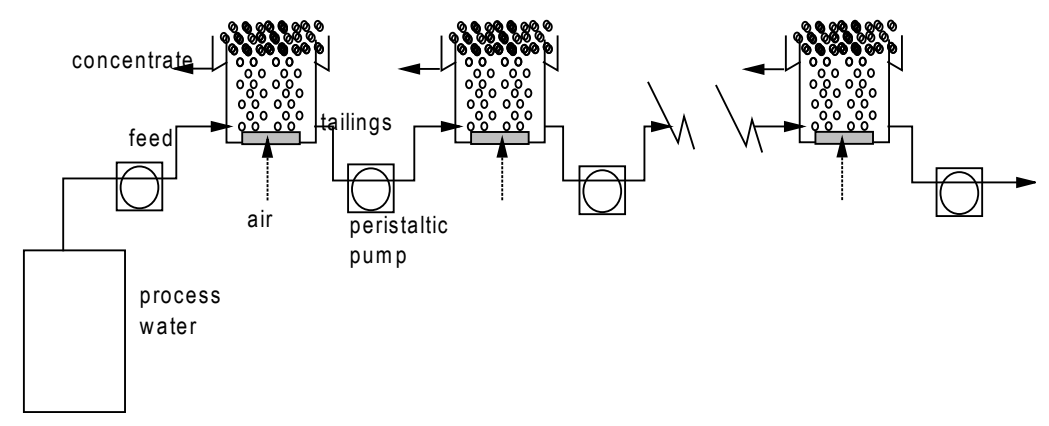

Fig. 7. Schematic representation of the experimental apparatus consisted of a series of five spargered flotation cells. 


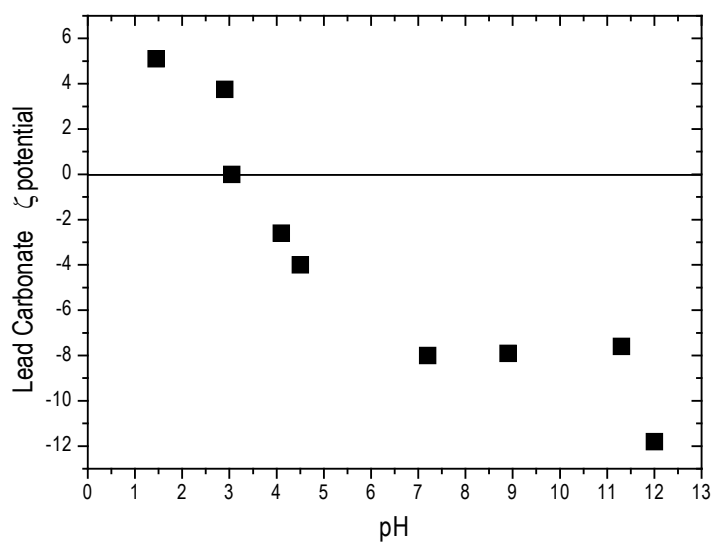

Fig. 8. Results of the electrokinetics measurements of lead carbonate in aqueous media showing the effect of $\mathrm{pH}$ on the lead carbonate zeta potential $(\xi)$.

concentration in the aqueous phase. Also, Dowfroth 250 was added to the water as frother $30 \mathrm{mgL}^{-1}$.

\section{Experimental procedure}

The experimental system consisted of five flotation cells, in a series array, operated under the same specified feed flow rates and gas flow rates for all experiments. When the experimental system attained conditions of steady state operation, which was defined by a stable position of the froth depth in each flotation cell, being almost the same froth depth in all flotation cell, the collection zone apparent residence time was estimated in each flotation cell the apparent residence time is a function of the height of the collection zone, $h_{z c}$, the superficial liquid velocity, $\mathrm{J}_{1}$ and the gas holdup, $\varepsilon_{\mathrm{g}}$, i.e., $\tau=\left(\mathrm{h}_{\mathrm{zc}} / \mathrm{J}_{1}\right) \times\left(1-\varepsilon_{\mathrm{g}}\right)$, (min).

Once the apparent residence time in the collection zone of the flotation cells was estimated, the longest of them was chosen as a reference, and the data for every experimental point taken after three times. The operating variables such as gas holdup, superficial gas velocity, and superficial liquid velocity were recorded and samples of concentrate, tailings, and feed were taken in this order for all flotation cells starting with the fifth one.
The experimental samples were taken, recording the sampling time and sample weight, to an absorption atomic spectrophotometer analysed in their lead content. With the assays information a mass balance was performed for all experiment to determine the lead mass recovery.

\section{Acknowledgements}

The authors wish to acknowledge the Instituto de Investigaciones Metalúrgicas (UMSNH) by the financial support to carry out the present work. Martín Reyes Pérez acknowledges the Consejo Nacional de Ciencia y Tecnología for a graduate studies fellowship.

\section{References}

1. Tratado universal del medio ambiente, tomo 4, Ed., Rezza, México, 1993, 31-37.

2. Sebba, F., in: Ion flotation, Ed. Elsevier Publisher, London. New York 1962.

3. Ghazy, S. E.; El-morsy, S. M.; Ragab, A. H. J. Appl. Sci. Environ. Manage. 2008, 12, 75-82.

4. Jamaleddin, O. E.; Martin, E. W.; Juan, H. V. Sep. Purif. Technol, 2000, 18, 25-36.

5. Doyle, F. Int. J. Miner. Process. 2003, 72, 387-399.

6. Maxwell, J. C., in: A Treatise of Electricity and Magnetism. $3^{\text {rd }}$ Edition, 1 (II), Chapter IX, Oxford University Press, London, 1892, 435-449.

7. Tavera, F. J.; Gomez, C. O.; Finch, J. A. Can. Metall. Quart. 1998. 37, 1, 19-25.

8. Banisi, S.; Finch, J. A. Miner. Eng. 1994, 7, 1555-1559.

9. Escudero, R. Ph. D. thesis. 1998 McGill University, Canada.

10. Gorain, B. K. Ph. D. thesis, 1997 University of Queensland, Australia.

11. Finch, J. A.; Dobby G. S., in: Column flotation, Ed. Pergamon Press, Oxford, 1990.

12. Levenspiel, O., in: Chemical Reaction Engineering, Ed., McGraw Hill, Inc, New York. 1972.

13. Tavera, F. J.; Escudero, R.; Finch, J. A. Int. J. Miner. Proc. 2001, $61,23-40$.

14. Shaban, E. G. Iran. J. Chem. Chem. Eng. 2007, 26, 83 - 92.

15. Tavera, F. J.; Escudero, R.; Uribe, A.; Finch, J. A. Afinidad 2000, LVII 490, 415-423.

16. Tavera, F. J.; Gómez, C. O.; Finch, J. A. Trans. Instn. Min. Met. 1996, 105, 99-104. 